\title{
Optimalisasi Kinerja Dosen Perguruan Tinggi Swasta Program Studi Akuntansi Dan Manajemen di Provinsi Riau
}

\author{
AFRIJAL \\ Dosen tetap Universitas Pasir Pengarayan \\ email: afrijal_ak@yahoo.com
}

\begin{abstract}
The purpose of this study was to determine the effect of leadership on organizational culture, influence of compensation on organizational culture, leadership influence on the performance of the lecturer, the effect of compensation on the performance of teachers and the influence of organizational culture on the performance of private college lecturer in Riau province. The whole object of research lecturer in Private University in three colleges namely Riau Islamic University (UIR), Lancang Kuning University (UNILAK) and the University of sand Pengaraian (UPP) at the Faculty of Economics and Management Studies Program Akuntasni totaling 68 people consisting of as many UIR 31 people, 25 and UPP UNILAK as many as 12 people with saturated sampling technique. The variables studied consisted of three independent variables and the dependent variable. The independent variable is leadership (X1), compensation (X2), and the culture of the organization, while the dependent variable is the performance of lecturers (Y). The method used in this study is a quantitative method. The results showed that the direct effect of leadership on organizational culture variables of 0.615. Then the variable compensation of organizational culture at 0.372. Leadership variables on the performance faculty at 0.174. Variable compensation on the performance faculty at 0.416 and variable influence of organizational culture on the performance faculty of 0,429. Then the variable indirect causal influence on the performance faculty leadership through organizational culture at 0.264 and compensation to the performance of 0,160 professors. Total causal influence of leadership on the performance of 0,438 professors, lecturers compensation to performance of 0.576 and organizational culture on the performance faculty of 0,429. Direct influence over the dominant variable affecting the compensation of faculty performance, but indirectly through the organizational culture of leadership that is greater than its effect on the performance of faculty compensation.
\end{abstract}

Keywords: Leadership, compensation, organizational culture, faculty performance.

Pendidikan adalah usaha sadar dalam bentuk kegiatan bimbingan, pengajaran dan/atau yang menyiapkan peserta didik menjadi manusia seutuhnya. Yang dimaksud dengan manusia seutuhnya adalah manusia yang beriman dan bertaqwa tehadap Allah SWT, serta berakhlaq mulia, memiliki pengetahuan dan keterampilan, sehat jasmani dan rohani, berkepribadian yang mantap, mandiri, serta memiliki tanggungjawab kemasyarakatan dan kebangsaan. Oleh karena itu pendidikan merupakan pilar utama dalam pembangunan nasional untuk mewujudkan masyarakat utama, adil dan makmur berdasarkan Pancasila dan UUD 1945 serta diridhai Allah SWT. Perguruan Tinggi adalah pusat penyelenggaraan dan pembangunan ilmu pengetahuan, teknologi dan kesenian, sebagai masyarakat ilmiah yang penuh cita-cita luhur, guna melaksanakan kehidupan berbangsa dalam rangka mencapai tujuan pendidikan nasional sebagaimana tercantum dalam pembukaan UUD 1945.

Dosen adalah pendidik profesional dan ilmuwan dengan tugas utama mentransformasikan, mengembangkan, dan menyebarluaskan ilmu pengetahuan, teknologi, dan seni melalui pendidikan, penelitian, dan pengabdian kepada masyarakat. Profesi dosen merupakan bidang pekerjaan khusus yang dilaksanakan berdasarkan prinsip sebagai berikut: Memiliki bakat, minat, panggilan jiwa, dan idealisme; Memiliki komitmen untuk meningkatkan mutu pendidikan, keimanan, ketakwaan, dan akhlak mulia; Memiliki kualifikasi akademik dan latar belakang pendidikan sesuai dengan bidang tugas; Memiliki kompetensi yang diperlukan sesuai dengan bidang tugas; Memiliki tanggung jawab atas pelaksanaan tugas keprofesionalan; Memperoleh penghasilan 
yang ditentukan sesuai dengan prestasi kerja; Memiliki kesempatan untuk mengembangkan keprofesionalan secara berkelanjutan dengan belajar sepanjang hayat; Memiliki jaminan perlindungan hukum dalam melaksanakan tugas keprofesionalan; Dosen wajib memiliki kualifikasi akademik, kompetensi, sertifikat pendidik, sehat jasmani dan rohani, dan memenuhi kualifikasi lain yang dipersyaratkan satuan pendidikan tinggi tempat bertugas, serta memiliki kemampuan untuk mewujudkan tujuan pendidikan nasional.

Dosen harus memiliki kualifikasi akademik yang diperoleh melalui pendidikan tinggi program pascasarjana yang terakreditasi sesuai dengan bidang keahlian, minimum : Lulusan program magister untuk program diploma atau program sarjana Lulusan program doktor untuk program pascasarjana. Sertifikat pendidik adalah bukti formal sebagai pengakuan yang diberikan kepada dosen sebagai tenaga profesional, diberikan setelah memenuhi persyaratan sebagai berikut: Memiliki pengalaman kerja sebagai pendidik pada perguruan tinggi sekurang-kurangnya 2 (dua) tahun; Memiliki jabatan akademik sekurang-kurangnya asisten ahli; dan Lulus sertifikasi yang dilakukan oleh perguruan tinggi terakreditasi yang menyelenggarakan program pengadaan tenaga kependidikan pada perguruan tinggi yang ditetapkan oleh Pemerintah RI.

Untuk memperoleh sertifikasi pendidik, maka dosen tersebut harus melalui uji kompetensi yang dilakukan dalam bentuk penilaian portofolio, yaitu merupakan penilaian pengalaman akademik dan profesional dengan menggunakan portofolio dosen. Penilaian portofolio dosen dilakukan untuk menentukan pengakuan atas kemampuan profesional dosen, dalam bentuk penilaian terhadap kumpulan dokumen yang mendeskripsikan: Kualifikasi akademik dan unjuk kerja tridharma perguruan tinggi; Persepsi dari atasan, sejawat, mahasiswa dan diri sendiri tentang kepemilikan kompetensi pedagogik, profesional, sosial dan kepribadian; dan Pernyataan diri tentang kontribusi dosen yang bersangkutan dalam pelaksanaan dan pengembangan tridharma perguruan tinggi.

Dalam melaksanakan tugas keprofesionalan, dosen berhak: memperoleh penghasilan di atas kebutuhan hidup minimum dan jaminan kesejahteraan sosial; mendapatkan promosi dan penghargaan sesuai dengan tugas dan prestasi kerja; memperoleh perlindungan dalam melaksanakan tugas dan hak atas kekayaan intelektual; memperoleh kesempatan untuk meningkatkan kompetensi, akses sumber belajar, informasi, sarana dan prasarana pembelajaran, serta penelitian dan pengabdian kepada masyarakat; memiliki kebebasan akademik, mimbar akademik, dan otonomi keilmuan; memiliki kebebasan dalam memberikan penilaian dan menentukan kelulusan peserta didik; dan memiliki kebebasan untuk berserikat dalam organisasi profesi/organisasi profesi keilmuan.

Dalam melaksanakan tugas keprofesionalan, dosen berkewajiban: melaksanakan pendidikan, penelitian, dan pengabdian kepada masyarakat; merencanakan, melaksanakan proses pembelajaran, serta menilai dan mengevaluasi hasil pembelajaran; meningkatkan dan mengembangkan kualifikasi akademik dan kompetensi secara berkelanjutan sejalan dengan perkembangan ilmu pengetahuan, teknologi, dan seni; bertindak objektif dan tidak diskriminatif atas dasar pertimbangan jenis kelamin, agama, suku, ras, kondisi fisik tertentu, atau latar belakang sosioekonomi peserta didik dalam pembelajaran; menjunjung tinggi peraturan perundang-undangan, hukum, dan kode etik, serta nilai-nilai agama dan etika; dan memelihara dan memupuk persatuan dan kesatuan bangsa. Uraian tersebut merupakan bentuk kinerja dosen dalam rangka meningkatkan mutu lulusan yang siap kerja.

Propinsi Riau merupakan salah satu daerah yang memiliki perguruan tinggi khususnya universitas yang saat ini sedang berkembang. Terdapat 6 Universitas Swasta 
dan 2 Universitas Negeri yang mengembangan sumber daya manusia di daerah ini. Dilihat dari Universitas Swasta perkembangannya cukup pesat, dimana pada lima tahun terakhir penambahan mencapai 100\% yakni dari 3 buah universitas (UIR, UNILAK dan ABDURAB) bertambah menjadi 3 buah yakni UNISI, UMRI dan UPP. Perguruan tinggi tersebut melayani berbagai program studi, namun program studi yang dominan dikembangkan adalah bidang ilmu ekonomi khususnya program studi akuntansi dan manajemen. Kecuali universitas ABDURAB yang tidak menyelenggarakan fakultas ekonomi. Permasalahan yang dihadapi dengan berkembangnya bidang ilmu ekonomi khususnya program studi Akuntansi dan Manajemen adalah berkaitan dengan kinerja dosen dalam melaksanakan tri dharma perguruan tingginya.

Berdasarkan data pelaksanaan tri dharma perguruan tinggi pada setiap universitas swasta dapat diketahui bahwa pada pelaksanaan pengajaran capaian mencapai $133 \%$ hal ini melebihi batas kewajiban dosen, kemudian pada bidang penelitian hanya mencapai $31,5 \%$ dan pengabdian hanya $27,5 \%$. Data ini menunjukkan bahwa rendahnya kinerja dosen dalam melaksanakan tugas tri dharmanya. Selain masalah kinerja dosen tersebut, dapat pula dilihat permasalahan lainnya seperti: permasalahan kompensasi dosen dalam melaksanakan pengajaran, penelitian dan pengabdian dan juga pergantian pimpinan,

Permasalahan lainnya pada masalah kompensasi yang diterima dosen swasta dalam melaksanakan tugas tridharmanya, dimana dosen lebih senang mengajar karena kelebihan mengajar dari batas sks (sistem kredit semester) yang ditetapkan mendapatkan tambahan penghasilan, paling tinggi di UIR sebesar Rp. 60.000,- per sks dan yang terendah di UPP yakni Rp. 37.500. per sks. Kemudian untuk penelitian paling tinggi $\mathrm{Rp}$. 3.000.000. dan paling rendah Rp. 1.500.000. Juga untuk pengabdian paling tinggi Rp.2.500.000. dan paling rendah Rp. 1.000.000,-, dosen kurang semangat dalam melaksanakan penelitian karena selain pekerjaannya rumit dan prosedurnya panjang kecenderungan dosen mendapatkan kompensasi yang relatif lebih rendah, apabila dibandingkan dengan biaya yang dikeluarkan tidak sebanding. Kemudian hal yang sama dirasakan dosen pada bidang pengabdian pada masyarakat, dimana masalah biaya menjadi kendala.

Permasalahan ditambah parah dengan kurangnya teladan dan motivasi dari pimpinan dalam merealisasikan pelaksanaan tridharmanya, dimana kurangnya terobosan untuk mendapatkan hibah penelitian dan pengabdian yang disediakan pemerintah. Juga karena kecenderungan bahwa dalam kurun waktu 10 tahun terakhir sudah beberapa kali dilakukan pergantian pimpinan yang memimpin Fakultas, hal ini menyebabkan sangat sedikitnya dosen perguruan tinggi swasta yang mendapatkan dana hibah tersebut karena pimpinan sering ganti.

Kemudian permasalahan lainnya mengarah kepada Dosen kurang puas terhadap manajerial kampus hal ini diindikasikan dari banyaknya keluhan dosen terhadap pelaksanaan administrasi kampus dan juga sistem manajerial yang diterapkan yang dianggapnya tidak jelas. Kampus seakan-akan hanya milik yayasan dan dikendalikan oleh yayasan, peran dosen sebagai aset kampus kurang mendapatkan porsi yang sesuai dengan idealnya. Juga kondisi atmosfir kampus yang kurang terasa adanya aktifitas yang mengarah kepada budaya akademis.

Menurut Tika (2005: 121) menyatakan kinerja sebagai hasil fungsi pekerjaan/kegiatan seseorang atau kelompok dalam suatu organisasi yang dipengaruhi oleh berbagai faktor untuk mencapai tujuan organisasi dalam periode waktu tertentu. Kemudian Lawler dan Porter dalam Sutrisno (2010: 170) menyatakan kinerja adalah kesuksesan seseorang dalam melaksanakan tugas. Kemudian menurut Miner dalam Sutrisno (2010: 170) menyatakan kinerja adalah bagaimana seseorang diharapkan dapat berfungsi dan berperilaku sesuai dengan 
tugas yang telah dibebankan kepadanya. Widodo (2001: 47) bahwa kinerja adalah sesuatu yang dicapai, prestasi yang diperlihatkan dan kemampuan kerja. Kemudian menurut Mangkunegara, (2000: 67) istilah kinerja dari kata job performance atau actual performance (prestasi kerja atau prestasi, sesungguhnya yang dicapai seseorang). Pengertian kinerja adalah hasil kerja secara kualitas dan kuantitas yang dicapai oleh seseorang dalam melaksanakan tugasnya sesuai dengan tanggung jawab yang diberikan kepadanya. Selanjutnya dapat dipahami kinerja aparat mempengaruhi kinerja organisasi dimana dia berperan sebagai pelaku.

Menurut Soeprihanto (2000: 8), secara lebih rinci menyebutkan bahwa tujuan penilaian pelaksanaan pekerjaan (kinerja) sebagai berikut: 1) Mengetahui keadaan keterampilan dan kemampuan setiap pegawai secara rutin. 2) Untuk digunakan sebagai dasar perencanaan bidang personalia, khususnya penyempurnaan kondisi kerja, peningkatan mutu dan hasil kerja. 3) Dapat digunakan sebagai dasar pengembangan dan pendayagunaan pegawai seoptimal mungkin, sehingga antara lain dapat diarahkan jenjang karirnya atau perencanaan karir, kenaikan pangkat dan kenaikan jabatan. 4) Mendorong terjadinya hubungan timbal balik antara atasan dan bawahan. 5) Mengetahui kondisi organisasi secara keseluruhan dari bidang personalia, khususnya kinerja pegawai. 6) Secara pribadi pegawai dapat mengetahui kekuatan dan kelemahan masing-masing sehingga dapat memacu perkembangan. 7) Hasil evaluasi kinerja dapat bermanfaat bagi penelitian dan pengembangan di bidang personalia secara keseluruhan.

Peraturan Menteri Pendidikan Nasional Republik Indonesia No. 19 Tahun 2008 tentang perguruan tinggi penyelenggara sertifikasi dosen, dan Peraturan No. 20 Tahun 2008 tentang penetapan in passing pangkat dosen bukan pegawai negeri sipil yang telah menduduki jabatan akademik pada perguruan tinggi yang diselenggarakan oleh masyarakat dengan pangkat pegawai negeri sipil, telah membuat gairah para dosen khususnya di lingkungan perguruan tinggi swasta untuk memulai memperhatikan jenjang akademiknya. Karena jenjang akademik adalah merupakan salah satu bentuk penilaian pemerintah atas kinerja seorang dosen.

Bagi suatu perguruan tinggi, salah satu pihak yang berperan strategis dalam meningkatkan kemajuan dan kualitas lembaga tersebut adalah kinerja dosen (lecturer). Sejalan dengan pernyataan tersebut Khoe Yao Tung dalam Achmad Sanusi dan Sanusi Uwes dalam Muhardi (2004), menyatakan bahwa "Dosen merupakan faktor kunci sukses (key success factor) dari upaya untuk meningkatkan mutu jasa pendidikan". Pendapat yang sama dikemukakan oleh Abdurrachman dan S. Marten Yogaswara dalam Muhardi (2004:34) bahwa "Nilai keberhasilan pendidikan sangat tergantung dari mutu pengajarnya. Dosen adalah orang yang sangat berperan dalam proses belajar mengajarnya".

Dosen harus mempunyai beberapa kualifikasi yang diperlukan bagi pelaksanaan profesinya, mengingat profesi dosen berbeda dengan profesi bidang yang lain. Selain memerlukan ilmu pengetahuan juga harus menyampaikan ilmunya kepada mahasiswa. Dengan tenaga dosen yang mempunyai motivasi, berkompeten dan berkualitas akan memudahkan penyampaian ilmu pengetahuan dan teknologi sehingga apa yang disampaikan kepada mahasiswa dapat diterima dan dikembangkan sesuai dengan kemampuan mahasiswa dengan kajian bidang ilmu yang dipilihnya. Di samping itu dosen juga harus mempunyai komitmen yang tinggi yang ditunjukkan dengan kehadiran pada waktu kerja, juga mempunyai rasa tanggung jawab terhadap ilmu yang diberikan kepada mahasiswa.

Untuk mengetahui tinggi rendahnya kinerja dosen dalam melakukan pekerjaannya maka diperlukan adanya system penilaian terhadap kinerja dosen. Penilaian kinerja adalah suatu cara yang digunakan untuk mengukur pekerjaan yang 
dilakukan sesuai dengan target yang telah ditetapkan. Sebagai tenaga professional, dosen yang bekerja dan menjalankan tugasnya, profesi juga perlakukan dilakukan penilaian dalam menjalankan pekerjaannya sebagai pendidik. Pentingnya penilaian kinerja dosen juga dikemukakan oleh Aiken Lewis R dalam Umi Narimawati (2005) "Bahwa penilaian terhadap kinerja dosen penting/ perlu dilakukan, mengingat dosen dalam posisi penting dalam mempengaruhi pelaksanaan pendidikan mahasiswanya maka tidak mengherankan apabila pemerintah, orang tua mahasiswa, serta yang lain memeprhatikan mutu pendidikan melalui kemampuan seorang dosen".

Menurut Ridwan (2011: 191) kinerja dosen adalah kualitas hasil kerja yang dilakukan dosen dalam pengajaran (proses belajar mengajar). Kesimpulan ini didasarkan pada konsep bahwa kinerja dosen adalah seperangkat perilaku yang ditunjukkan oleh dosen pada saat menjalankan tugas dan kewajibannya dalam bidang pengajaran dengan dimensi: kemampuan, prakarsa/inisiatif, ketepatan waktu, kualitas hasil kerja dan komunikasi. Kemudian Ridwan (2011: 216) juga menjelaskan mengenai uraian dari masing-masing dimensi sebagai berikut: Kemampuan yakni penguasaan materi dan penguasaan metode pengajaran. Inisitif yakni berpikir positif yang lebih baik dan mewujudkan kreatifitas dan pencapaian prestasi. Ketepatan waktu yakni pemanfaatan waktua kedatangan dan pemanfaatan waktu pulang. Kualitas hasil kerja yakni kepuasan mahasiswa dan pemahaman mahasiswa serta prestasi mahasiswa. Komunikasi yakni mutu penyampaian dan juga penguasaan keadaan kelas.

Sehubungan dengan penilaian kinerja, Craigh dalam umi Narimawati (2005) mengidentifikasi sumber - sumber masalah dalam penilaian kinerja, yaitu; (a) competency problem, (b) motivational problem, dan (c) leadership and organizational problem. Dengan demikian kinerja seseorang sangat dipengaruhi oleh kompetensi yang dimiliki oleh setiap individu yang dilakukan evaluasi.
Motivasi seseorang dalam melakukan tugas serta gaya kepemimpinan yang berlaku, aturan, dan lingkungann dari suatu organiasi tempat seseorang bekerja.

Berdasarkan pendapat tersebut di atas, jelas dapat dikatakan bahwa kinerja adalah suatu kumpulan total dari perilaku kerja yang ada pada pekerja, dalam kaitannya dengan kinerja dosen yaitu perilaku kerja dosen yakni dalam melaksanakan tri dharma perguruan tinggi yakni pengajaran, penelitian dan pengadian masyarakat.

Menurut Robins (2001 : 273), bahwa: "Sejumlah faktor struktural menunjukkan suatu hubungan ke kinerja. Di antara faktor yang lebih menonjol adalah persepsi peran, norma, inekuitas status, ukuran kelompok, susunan demografinya, tugas kelompok dan kekohesifan (saling terkait)". Sedangkan menurut Mangkunegara (2002: 67) mengatakan bahwa faktor-faktor yang mempengaruhi kinerja pegawai adalah: 1) Faktor kemampuan dan 2) Faktor motivasi.

Kemudian faktor-faktor yang mempengaruhi kinerja pegawai, secara rinci dikemukakan oleh Mangkunegara (2002: 67) menyatakan bahwa setiap usaha untuk mengetahui mengapa seseorang berprilaku seperti yang dilakukan selama ini dalam organisasi memerlukan pemahaman tentang: (1) individu yang memiliki kemampuan, keterampilan mencakup mental dan fisik, latar belakang: keluarga, umur dan jenis kelamin, (2) organisasi meliputi : sumber daya, kepemimpinan, imbalan dan prosedur kerja, tim work dan (3) psikologi meliputi: persepsi, sikap, kepribadian dan motivasi serta komitmen. Lebih dari itu, adapun yang mempengaruhi faktor-faktor kinerja dalam suatu organisasi adalah faktor kemampuan dan faktor motivasi.

Berdasarkan uraian tersebut, maka dapat disimpulkan bahwa kinerja dosen adalah kualitas hasil kerja yang dilakukan dosen dalam pengajaran (proses belajar mengajar) dan juga sebagai seperangkat perilaku yang ditunjukkan oleh dosen pada 
saat menjalankan tugas dan kewajibannya dalam bidang pengajaran dengan dimensi: kemampuan, prakarsa/inisiatif, ketepatan waktu, kualitas hasil kerja dan komunikasi. Uraian dari masing-masing dimensi sebagai berikut: Kemampuan yakni penguasaan materi dan penguasaan metode pengajaran. Inisitif yakni berpikir positif yang lebih baik dan mewujudkan kreatifitas dan pencapaian prestasi. Ketepatan waktu yakni pemanfaatan waktua kedatangan dan pemanfaatan waktu pulang. Kualitas hasil kerja yakni kepuasan mahasiswa dan pemahaman mahasiswa serta prestasi mahasiswa. Komunikasi yakni mutu penyampaian dan juga penguasaan keadaan kelas.

Menurut Daryanto (2011: 18) bahwa kepemimpinan berasal dari kata pimpin yang memuat dua hal pokok, yaitu: pertama, pemimpin sebagai subjek dan yang kedua yang dipimpin sebagai objek. Kata pimpin mengandung pengertian mengarahkan, membina atau mengatur, menuntun dan juga menunjukkan ataupun mempengaruhi. Pemimpin mempunyai tanggung jawab baik secara fisik maupun spiritual terhadap keberhasilan aktivitas kerja dari yang dipimpin, sehingga menjadi pemimpin itu tidak mudah dan tidak akan setiap orang mempunyai kesamaan di dalam menjalankan kepemimpinannya.

Indikator kepemimpinan adalah sekumpulan dari serangkaian kemampuan dan sifat-sifat kepribadian, termasuk di dalamnya kewibawaan, untuk dijadikan sebagai sarana dalam rangka menyakinkan yang dipimpinnya agar mereka mau dan dapat melaksanakan tugas-tugas yang dibebankan kepadanya dengan rela, penuh semangat, ada kegembiraan batin, serta merasa tidak dipaksa. pemimpin yang efektif adalah:

a. Pemimpin yang terus belajar dari kesalahan merupakan pimpinan dalam hal ini yang berkaitan dengan kinerja dosen seperti ketua jurusan, sekretaris jurusan dan dekan bahkan rektor dalam rangka memperbaiki berbagaia kekeliruan dan kesalahan dalam perencanaan dan dalam pelaksanaan dosen apakah sudah diperbaiki dan sudah sesuai dengan kondisi yang ada.

b. Berusaha memperbaiki dengan cara yang bijak merupakan kebijakan para pemimpin dalam menyelenggarakan pendidikan sangat berbeda dengan kondisi perusahaan, karena dosen adalah kaum intelektual sehingga perlu sangat diperhatikan kearifan dalam mengambil keputusan.

c. Memberikan kesempatan pada karyawan untuk memberikan kritik merupakan bersikap kritis adalah sikap yang diharapkan dari dosen, apakah dosen selama ini kritis terhadap penyelenggaraan pendidikan di kampus, hal ini sangat mengambarkan kondisi kesempatan dalam memberikan masukan kepada lembaga dalam rangka perbaikan lembaga pendidikan.

d. Saran perbaikan merupakan bentuk usulan yang diberikan dalam rangka membantu memecahkan masalah yang dihadapi pimpinan dari anggota, pimpinan yang mengharapkan saran dari para dosen merupakan bentuk pimpinan yang baik.

Menurut Kadarisman (2012: 11) kompensasi adalah apa yang seorang pegawai terima sebagai balasan dari pekerjaan yang diberikan. Baik upah per jam ataupun gaji periodik didesain dan dikelola oleh bagian sumberdaya manusia. Kompensasi yang diberikan ada yang berbentuk uang dan ada pula yang berbentuk tidak uang. Kompensasi yang berwujud upah pada umumnya berbentuk uang, sehingga kemungkinan nilai riilnya turun naik.

Indikator kompensasi ialah suatu penerimaan sebagai suatu imbalan dari pemberian kerja kepada penerima kerja untuk suatu pekerjaan atau jasa yang telah dan akan dilakukan, berfungsi sebagai jaminan kelangsungan kehidupan yang layak bagi kemanusiaan. Dimensi kompensasi adalah sederhana, spesifik, dapat dicapai dan dapat diukur. 
a. Kecukupan sebagai imbalan dalam memenuhi kebutuhan dasar (kelayakan).

b. Kewajaran dilihat dari sudut pasar tenaga kerja (eksternal organisasi)

c. Keadilan dari sudut kemampuan organisasi (internal organisasi) dalam memberikan pembayaran.

d. Memperhatikan perbedaan untuk setiap pegawai organisasi berupa kewajiban dan tanggung jawabnya.

Ndraha (2005: 74) mengatakan budaya organisasi merupakan gaya dan cara hidup organisasi sebagai pencerminan dari nilai-nilai atau kepercayaan yang selama ini dianut oleh seluruh anggota organisasi. Juga merupakan pola kepercayaan, nilai ritual, mitos para anggota suatu organisasi yang mempengaruhi perilaku semua individu dan kelompok di dalam organisasi. Termasuk juga aktivitas budaya organisasi mempengaruhi kehidupan organisasi seperti bagaimana keputusan dibuat, siapa yang membuatnya, bagaimana imbalan dibagikan, bagaimana orang diperlakukan dan bagaimana organisasi memberi respon kepada lingkungannya, dan lain-lain.

Indikator budaya organisasi adalah sebagai gaya dan cara hidup organisasi sebagai pencerminan dari nilai-nilai atau kepercayaan yang selama ini dianut oleh seluruh anggota organisasi dalam mencapai tujuannya. Dimensi dari budaya organisasi berupa:

a. Menghargai pendapat orang lain yakni penghargaan terhadap pendapat orang lain secara obyektif

b. Pemikiran rasional dan kritis-analitis dengan tanggungjawab moral

c. Kebiasaan membaca yakni dalam rangka menambah pengetahuan

d. Penambahan ilmu dan wawasan

e. Kebiasaan meneliti dan mengabdi kepada masyarakat

f. Penulisan artikel, makalah, buku.

g. Diskusi ilmiah

h. Proses belajar-mengajar

i. Manajemen perguruan tinggi yang baik

\section{METODE}

Metode penelitian yang digunakan adalah metode kuantitatif. Populasi dalam penelitian ini adalah seluruh dosen di Universitas Swasta pada tiga perguruan tinggi diambil sampel sebanyak 68 orang. Teknik pengambilan sampel dengan menggunakan teknik sampling jenuh. Teknik pengumpulan data dilakukan dengan cara penelitian lapangan dan studi kepustakaan. Data penelitian dianalisis dengan menggunakan teknik analisa jalur.

\section{HASIL}

Berdasarkan hasil penelitian diketahui bahwa dengan menggunakan koefisien jalur dapat dihitung pengaruh kausal antar variabel yang dapat dibedakan menjadi tiga yaitu:

1. Pengaruh kausal langsung (direct causal effect atau DE) adalah pengaruh satu avriabel eksogen terhadap variabel endogen tanpa melalui variabel endogen lain (variabel antara)

2. Pengaruh kausal tidak langsung (Indirect causal effect atau IE) adalah pengaruh satu avriabel eksogen terhadap variabel endogen yang terjadi melalui variabel endogen lain (dengan variabel antara) yang terdapat dalam satu model yang dianalisis.

3. Pengaruh kausal total (Total causal effect atau TE) adalah jumlah pengaruh kausal langsung dan pengaruh kausal tidak langsung secara dirangkum dalam tabel berikut :

Dari hasil perhitungan diketahui bahwa pengaruh kepemimpinan terhadap kinerja dosen melalui budaya organisasi lebih besar dibandingkan pengaruh kompensasi terhadap kinerja dosen melalui budaya organisasi. Pengaruh kausal langsung (direct causal effect atau DE) adalah pengaruh satu avriabel eksogen terhadap variabel endogen tanpa melalui variabel endogen lain (variabel antara), yakni variabel kepemimpinan terhadap budaya organisasi sebesar 0,615. Kemudian variabel kompensasi terhadap budaya 


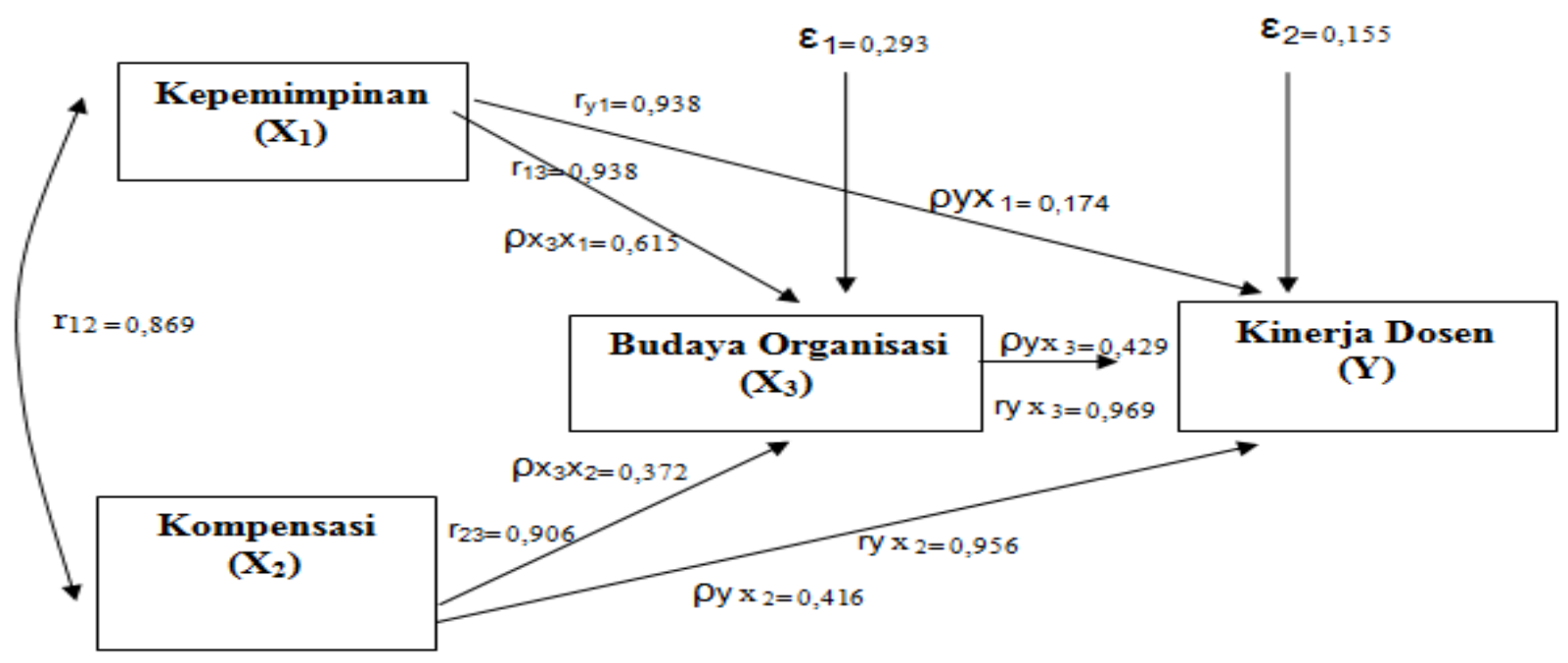

organisasi sebesar 0,372. Variabel kepemimpinan terhadap kinerja dosen sebesar 0,174 . Variabel kompensasi terhadap kinerja dosen sebesar 0,416 dan pengaruh variabel budaya organisasi terhadap kinerja dosen sebesar 0,429.

Kemudian pengaruh kausal tidak langsung (Indirect causal effect atau IE) adalah pengaruh satu avriabel eksogen terhadap variabel endogen yang terjadi melalui variabel endogen lain (dengan variabel antara) yang terdapat dalam satu model yang dianalisis. Variabel kepemimpinan terhadap kinerja dosen melalui budaya organisasi sebesar 0,264 dan kompensasi terhadap kinerja dosen sebesar 0,160 .

Pengaruh kausal total (Total causal effect atau TE) adalah jumlah pengaruh kausal langsung dan pengaruh kausal tidak langsung variabel kepemimpinan terhadap kinerja dosen sebesar 0,438, kompensasi terhadap kinerja dosen sebesar 0,576 dan budaya organisasi terhadap kinerja dosen sebesar 0,429 .

Jadi dapat diketahui secara langsung pengaruh variabel kompensasi lebih dominan mempengaruhi kinerja dosen, namun secara tidak langsung yakni melalui budaya organisasi kepemimpinan lebih besar pengaruhnya terhadap kinerja dosen dibandingkan dengan kompensasi.

Berdasarkan hasil dari koefisien jalur pada sub-struktur 1 dan sub-struktur 2 maka dapat digambarkan secara keseluruhan yang menggambarkan hubungan kausal empiris antar variabel $\mathrm{X}_{1}, \mathrm{X}_{2}$ dan $\mathrm{X}_{3}$ terhadap Y sebagai berikut:

Hasil dari koefisien jalur pada substruktur 1 dan sub-struktur 2 berubah menjadi persamaan struktur yaitu:

$$
\begin{aligned}
\mathrm{X}_{3} & =\rho \mathrm{x}_{3} \mathrm{x}_{1} \mathrm{X} 1+\rho \mathrm{x}_{3} \mathrm{x}_{2} \mathrm{X} 2+\rho \mathrm{x}_{3} \varepsilon_{1} \text { dan } R^{2} \mathrm{x}_{3} \mathrm{x}_{2} \mathrm{x}_{1} \\
& =0,615 \mathrm{X} 1+0,372 \mathrm{X} 2+0,293 \varepsilon_{1} \text { dan } 0,914 \\
\mathrm{Y} & =\rho \mathrm{yx}_{1} \mathrm{X}_{1}+\rho \mathrm{yx}_{2} \mathrm{X}_{2}+\rho \mathrm{yx}_{3} \mathrm{X}_{3}+\rho \mathrm{y} \varepsilon_{2} \text { dan } R^{2} \mathrm{y} \mathrm{x}_{3} \mathrm{x}_{2} \mathrm{x}_{1} \\
& =0,174 \mathrm{X} 1+0,416 \mathrm{X} 2+0,429 \mathrm{X} 3+0,155 \text { dan } 0,976
\end{aligned}
$$

\section{PEMBAHASAN}

Berdasarkan hasil penelitian, bahwa pengujian hipotesis yang dilakukan, diperoleh bukti bahwa kepemimpinan berpengaruh positif dan signifikan terhadap budaya organisasi, kompensasi berpengaruh positif dan signifikan terhadap budaya organisasi, kepemimpinan berpengaruh positif dan signifikan terhadap kinerja dosen, kompensasi berpengaruh positif dan signifikan terhadap kinerja dosen dan budaya organisasi berpengaruh positif dan signifikan terhadap kinerja dosen.

Penjelasan dari fakta tersebut akan dibahas secara rinci sebagai berikut:

\section{Pengaruh kepemimpinan terhadap budaya organisasi}

Salah satu bentuk dari kepemimpinan yang membentuk budaya 
organisasi kondusif adalah sarana dalam rangka menyakinkan yang dipimpinnya agar mereka mau dan dapat melaksanakan tugastugas yang dibebankan kepadanya dengan rela, penuh semangat, ada kegembiraan batin, serta merasa tidak dipaksa. pemimpin yang efektif. Hasil peelitian yang menarik menunjukkan bahwa:

i. Sebagian dosen berpendapat bahwa pemimpin PTS pada Fakutas Ekonomi jurusan akuntansi dan manajemen sebagian sudah cukup terus belajar dari kesalahan merupakan pimpinan dalam hal ini yang berkaitan dengan kinerja dosen seperti ketua jurusan, sekretaris jurusan dan dekan bahkan rektor dalam rangka memperbaiki berbagaia kekeliruan dan kesalahan dalam perencanaan dan dalam pelaksanaan dosen apakah sudah diperbaiki dan sudah sesuai dengan kondisi yang ada sehingga hal ini cukup membangun budaya organisasi dalam aktivitas kampus.

ii. Adanya kepemimpinan yang sudah cukup baik terus berusaha memperbaiki dengan cara yang bijak merupakan kebijakan para pemimpin dalam menyelenggarakan pendidikan sangat berbeda dengan kondisi perusahaan, karena dosen adalah kaum intelektual sehingga perlu sangat diperhatikan kearifan dalam mengambil keputusan. Hal ini berdampak terhadap terciptanya budaya organisasi kampus yang kondusif.

iii. Sebagian pimpinan memberikan kesempatan pada karyawan untuk memberikan kritik merupakan bersikap kritis adalah sikap yang diharapkan dari dosen, apakah dosen selama ini kritis terhadap penyelenggaraan pendidikan di kampus, hal ini sangat mengambarkan kondisi kesempatan dalam memberikan masukan kepada lembaga dalam rangka perbaikan lembaga pendidikan sehingga budaya tercipta dengan cukup baik.

iv. Sebagian pimpinan memberikan saran perbaikan merupakan bentuk usulan yang diberikan dalam rangka membantu memecahkan masalah yang dihadapi pimpinan dari anggota, pimpinan yang mengharapkan saran dari para dosen merupakan bentuk pimpinan yang baik sehingga budaya organisasi dapat berjalan dan kondusif.

\section{Pengaruh kompensasi terhadap budaya organisasi}

Pengaruh kompensasi terhadap budaya organsiasi berkaitan dengan apa yang seorang pegawai terima sebagai balasan dari pekerjaan yang diberikan, kecukupan sebagai imbalan dalam memenuhi kebutuhan dasar (kelayakan), kewajaran dilihat dari sudut pasar tenaga kerja (eksternal organisasi), keadilan dari sudut kemampuan organisasi (internal organisasi) dalam memberikan pembayaran dan memperhatikan perbedaan untuk setiap pegawai organisasi berupa kewajiban dan tanggung jawabnya. Salah satu bentuk dari kompensasi yang membentuk budaya organisasi kondusif adalah dosen mendapatkan honor dalam melaksanakan kegiatan bimbingan skripsi mahasiswa sehingga kampus menjadi tempat menimba ilmu. Kemudian juga hal yang membuat kompensasi kurang mendukung budaya organisasi adalah dosen kurang mendapatkan gaji yang cukup untuk memenuhi kebutuhan hidup keluarga sehingga kurang tampak budaya membaca di kampus dan kurangnya kegiatan debat dalam rangka mencari solusi, karena dosen sibuk dengan urusan di luar kampus untuk mencari tambahan kebutuhan keluarga.

Hasil peelitian yang menarik menunjukkan bahwa:

a. Kecukupan sebagai imbalan dalam memenuhi kebutuhan dasar (kelayakan) dalam mendapatkan gaji yang cukup untuk memenuhi kebutuhan keluarga sudah mencukupi, kemudian sudah cukup mendapatkan tambahan penghasilan dari jabatan yang diemban dan sudah cukup mendapatkan insentif setiap melaksanakan tugas tambahan, serta mendapatkan honor dalam melaksanakan kegiatan bimbingan skripsi mahasiswa dan mendapat 
penghargaan dari hasil kerja yang dilakukan. Sehingga hal ini berpengaruh pada kegiatan kampus yang kurang aktif dan juga dosen banyak yang mencari sampingan mengajar di tempat lain.

b. Kewajaran dilihat dari sudut pasar tenaga kerja (eksternal organisasi) berupa mendapatkan upah standar UMR, mendapatkan kompensasi berdasarkan kompetensi yang dimiliki, mendapatkan kepuasan dari kompensasi yang diperoleh, termotivasi bekerja dari kompensasi yang diberikan dan selalu berusaha meningkatkan kinerja dalam rangka menambah kompensasi sudah cukup wajar. Sehingga dosen selalu membanding-bandingkan apa yang telah mereka peroleh di tempat mereka bekerja dan mencari tempat yang lebih menjanjikan.

c. Keadilan dari sudut kemampuan organisasi (internal organisasi) dalam memberikan pembayaran dinilai masih dalam kategori cukup dimana dosen sudah mendapatkan perlakuan yang adil dalam penggajian, semakin tinggi jabatan fungsional maka gaji yang diperoleh semakin besar, Dosen yang menjabat struktural mendapatkan tambahan penghasilan, semakin berat jabatan struktural yang diemban maka semakin besar tunjangan diperoleh, peningkatan penghasilan dapat dicapai dengan kerja keras. Sehingga muncul tuntutan dari dosen kepada lembaga untuk meningkatkan kompensasi yang mereka terima.

d. Memperhatikan perbedaan untuk setiap pegawai organisasi berupa kewajiban dan tanggung jawabnya yang selama ini sudah cukup dimana Lembaga memperhatikan beban kerja dosen dalam membagi mata kuliah, pembagian beban kerja menjadi diskusi di setiap semester oleh dosen bersama prodi, setiap dosen mendapatkan porsi yang sama dalam mengajar sesuai kemampuan, setiap dosen diperlakukan sama untuk mendapatkan kesempatan berkarir dan dosen yang lebih senior mendapatkan proporsi sesuai dengan kontribusinya. Sehingga sebagian dosen kurang aktif di kampus.

\section{Pengaruh kepemimpinan terhadap kinerja dosen}

Pengaruh kepemimpinan terhadap kinerja dosen berkaitan dengan sikap pimpinan PTS yang selalu mencari kebenaran ilmiah melalui kegiatan akademik dalam masyarakat akademik, yang mengembangkan kebebasan berpikir, keterbukaan, pikiran kritis-analitis; rasional dan obyektif oleh warga masyarakat akademik. Dalam rangka meningkatkan kinerja dosen di kampus yakni menjalankan tri dharma perguruan tinggi. Salah satu bentuk dari kepemimpinan yang membentuk kinerja dosen kepemimpinan yang memiliki strategi dalam mencapai visi dimana hal ini mengarah kepada visi perguruan tinggi yang sasaran kerjanya adalah dosen dalam menjalankan tri dharma perguruan tingginya yakni dalam melaksanakan pengajaran, penelitian dan pengabdian kepada masyarakat. Namun hal yang paling rendah dipandang adalah kepemipinan pada PTS masih belum memiliki standar operasi yang jelas dan masih kurang mau menerima saran dari bawahan hal ini berpengaruh terhadap kinerja dosen yakin dalam rangka melaksanakan program pimpinan untuk menjalankan tri dharma perguruan tinggi.

Hasil peelitian yang menarik menunjukkan bahwa:

a. Sebagian dosen berpendapat bahwa pemimpin PTS pada Fakutas Ekonomi jurusan akuntansi dan manajemen sebagian sudah cukup terus belajar dari kesalahan merupakan pimpinan dalam hal ini yang berkaitan dengan kinerja dosen seperti ketua jurusan, sekretaris jurusan dan dekan bahkan rektor dalam rangka memperbaiki berbagaia kekeliruan dan kesalahan dalam perencanaan dan dalam pelaksanaan dosen apakah sudah diperbaiki dan sudah sesuai dengan kondisi yang ada sehingga dapat meningkatkan kinerja dosen melaksanakan tri dharma 
perguruan tinggi.

b. Adanya kepemimpinan yang sudah cukup baik terus berusaha memperbaiki dengan cara yang bijak merupakan kebijakan para pemimpin dalam menyelenggarakan pendidikan sangat berbeda dengan kondisi perusahaan, karena dosen adalah kaum intelektual sehingga perlu sangat diperhatikan kearifan dalam mengambil keputusan. Hal ini berdampak terhadap terciptanya kinerja dosen melaksanakan tri dharma perguruan tinggi.

c. Sebagian pimpinan memberikan kesempatan pada karyawan untuk memberikan kritik merupakan bersikap kritis adalah sikap yang diharapkan dari dosen, apakah dosen selama ini kritis terhadap penyelenggaraan pendidikan di kampus, hal ini sangat mengambarkan kondisi kesempatan dalam memberikan masukan kepada lembaga dalam rangka perbaikan lembaga pendidikan sehingga dapat meningkatkan kinerja dosen melaksanakan tri dharma perguruan tinggi.

d. Sebagian pimpinan memberikan saran perbaikan merupakan bentuk usulan yang diberikan dalam rangka membantu memecahkan masalah yang dihadapi pimpinan dari anggota, pimpinan yang mengharapkan saran dari para dosen merupakan bentuk pimpinan yang baik sehingga dapat meningkatkan kinerja dosen melaksanakan tri dharma perguruan tinggi.

\section{Pengaruh kompensasi terhadap kinerja dosen}

Pengaruh kompensasi terhadap kinerja dosen berkaitan dengan apa yang seorang pegawai terima sebagai balasan dari pekerjaan yang diberikan, kecukupan sebagai imbalan dalam memenuhi kebutuhan dasar (kelayakan), kewajaran dilihat dari sudut pasar tenaga kerja (eksternal organisasi), keadilan dari sudut kemampuan organisasi (internal organisasi) dalam memberikan pembayaran dan memperhatikan perbedaan untuk setiap pegawai organisasi berupa kewajiban dan tanggung jawabnya sehingga anggota organisasi dapat bekerja dengan semaksimal mungkin.

Salah satu bentuk dari kompensasi yang membentuk kinerja dosen adalah dosen mendapatkan honor dalam melaksanakan kegiatan bimbingan skripsi mahasiswa sehingga kampus menjadi tempat menimba ilmu. Kemudian juga hal yang membuat kompensasi kurang mendukung kinerja dosen adalah dosen kurang mendapatkan gaji yang cukup untuk memenuhi kebutuhan hidup keluarga sehingga kegiatan penelitian dan pengabdian kurang mendapatkan perhatian dari dosen dalam pelaksanaan tugasnya.

Hasil peelitian yang menarik menunjukkan bahwa:

a. Kecukupan sebagai imbalan dalam memenuhi kebutuhan dasar (kelayakan) dalam mendapatkan gaji yang cukup untuk memenuhi kebutuhan keluarga sudah mencukupi, kemudian sudah cukup mendapatkan tambahan penghasilan dari jabatan yang diemban dan sudah cukup mendapatkan insentif setiap melaksanakan tugas tambahan, serta mendapatkan honor dalam melaksanakan kegiatan bimbingan skripsi mahasiswa dan mendapat penghargaan dari hasil kerja yang dilakukan. Sehingga hal ini berpengaruh pada pelaksanaan kinerja dosen melaksanakan tri dharma perguruan tingginya.

b. Kewajaran dilihat dari sudut pasar tenaga kerja (eksternal organisasi) berupa mendapatkan upah standar UMR, mendapatkan kompensasi berdasarkan kompetensi yang dimiliki, mendapatkan kepuasan dari kompensasi yang diperoleh, termotivasi bekerja dari kompensasi yang diberikan dan selalu berusaha meningkatkan kinerja dalam rangka menambah kompensasi sudah cukup wajar. Sehingga hal ini berpengaruh pada pelaksanaan kinerja dosen melaksanakan tri dharma perguruan 
tingginya.
c. Keadilan dari sudut kemampuan organisasi (internal organisasi) dalam memberikan pembayaran dinilai masih dalam kategori cukup dimana dosen sudah mendapatkan perlakuan yang adil dalam penggajian, semakin tinggi jabatan fungsional maka gaji yang diperoleh semakin besar, Dosen yang menjabat struktural mendapatkan tambahan penghasilan, semakin berat jabatan struktural yang diemban maka semakin besar tunjangan diperoleh, peningkatan penghasilan dapat dicapai dengan kerja keras. Sehingga hal ini berpengaruh pada pelaksanaan kinerja dosen melaksanakan tri dharma perguruan tingginya.

d. Memperhatikan perbedaan untuk setiap pegawai organisasi berupa kewajiban dan tanggung jawabnya yang selama ini sudah cukup dimana Lembaga memperhatikan beban kerja dosen dalam membagi mata kuliah, pembagian beban kerja menjadi diskusi di setiap semester oleh dosen bersama prodi, setiap dosen mendapatkan porsi yang sama dalam mengajar sesuai kemampuan, setiap dosen diperlakukan sama untuk mendapatkan kesempatan berkarir dan dosen yang lebih senior mendapatkan proporsi sesuai dengan kontribusinya. Sehingga hal ini berpengaruh pada pelaksanaan kinerja dosen melaksanakan tri dharma perguruan tingginya.

\section{Pengaruh budaya organisasi terhadap kinerja dosen}

Pengaruh budaya organisasi terhadap kinerja dosen berkaitan dengan sikap hidup yang selalu mencari kebenaran ilmiah melalui kegiatan akademik dalam masyarakat akademik, yang mengembangkan kebebasan berpikir, keterbukaan, pikiran kritis-analitis; rasional dan obyektif oleh warga masyarakat akademik. Penghargaan terhadap pendapat orang lain secara obyektif; pemikiran rasional dan kritis-analitis dengan tanggungjawab moral; kebiasaan membaca; penambahan ilmu dan wawasan; kebiasaan meneliti dan mengabdi kepada masyarakat; penulisan artikel, makalah, buku; diskusi ilmiah; proses belajar-mengajar, Manajemen perguruan tinggi yang baik.

a. Kampus cukup menghargai pendapat dengan diiringi bukti, cukup menghargai saran dengan solusi dan hal ini berpengaruh terhadap insiatif dosen dalam melaksanakan tugasnya di lapangan. Kritik dan saran yang diberikan dalam rangka membangun sangat membuat dosen berpikir positif dalam mewujudkan kreatifitas pencapaian prestasi.

b. Masyarakat kampus cukup memiliki pemikiran rasional dan kritis-analitis dengan tanggungjawab moral sehingga kualitas hasil kerja sebagai indikator kinerja dapat lebih baik.

c. Masih rendahnya kebiasaan membaca dari kalangan dosen sehingga kualitas hasil kerja dari warga kampus kurang meningkat sehingga kepuasan mahasiswa, pemahaman mahasiswa dan prestasi mahasiswa dalam pembelajaran ikut terpengauh.

d. Warga kampus cukup selalu menambah ilmu dan wawasan hal ini berdampak terhadap peningkatan kemampuan dosen dalam rangka mengembangkan ilmu pengetahuan.

e. Warga kampus cukup memiliki kebiasaan meneliti dan mengabdi kepada masyarakat sehingga terjalin komunikasi dengan pihak yang berkepentingan terhadap perguruan tinggi dalam hal ini adalah masyarakat.

f. Kampus cukup selalu melakukan penulisan artikel, makalah, buku sehingga dosen dituntut untuk selalu meningkatkan kualitas hasil kerja dari waktu ke waktunya.

g. Kampus cukup selalu melaksanakan diskusi ilmiah sehingga dosen dapat meningkatkan kemampuan dalam melaksanakan tugasnya yakni tri dharma perguruan tinggi.

h. Kampus cukup selalu melaksanakan proses belajar-mengajar sehingga 
kualitas hasil kerja dalam rangka memuaskan mahasiswa dan memberikan pemahaman serta meningkatkan prestasi mahasiswa ikut terpengaruh.

i. Manajemen perguruan tinggi selalu melaksanakan pengelolaan kegiatan kampus sehingga komunikasi selalu terjalin dengan warga kampus dan dosen dapat meningkatkan kinerjanya.

\section{SIMPULAN}

Kesimpulan yang dapat diambil dari penelitian ini adalah sebagai berikut: Kepemimpinan berpengaruh terhadap budaya organisasi pada Fakultas Ekonomi Prodi Akuntansi dan Manajemen. Dari hasil pengolahan data diketahui pengaruh kepemimpinan $\left(\mathrm{X}_{1}\right)$ terhadap budaya organisasi $\left(\mathrm{X}_{3}\right)$ sebesar 0,615. Kompensasi berpengaruh terhadap budaya organisasi pada Fakultas Ekonomi Prodi Akuntansi dan Manajemen. Dari hasil pengolahan data diketahui pengaruh kompensasi $\left(\mathrm{X}_{2}\right)$ terhadap budaya organisasi $\left(\mathrm{X}_{3}\right)$ sebesar 0,372 . Kepemimpinan berpengaruh terhadap kinerja dosen pada Fakultas Ekonomi Prodi Akuntansi dan Manajemen. Dari hasil pengolahan data diketahui pengaruh kepemimpinan $\left(\mathrm{X}_{1}\right)$ yang secara langsung mempengaruhi kinerja dosen (Y) sebesar 0,174. Kompensasi berpengaruh terhadap kinerja dosen pada Fakultas Ekonomi Prodi Akuntansi dan Manajemen. Dari hasil pengolahan data diketahui pengaruh kompensasi $\left(\mathrm{X}_{2}\right)$ yang secara langsung mempengaruhi kinerja dosen (Y) sebesar 0,416. budaya organisasi berpengaruh terhadap kinerja dosen pada Fakultas Ekonomi Prodi Akuntansi dan Manajemen. Dari hasil pengolahan data diketahui pengaruh budaya organisasi $\left(\mathrm{X}_{3}\right)$ yang secara langsung mempengaruhi kinerja dosen (Y) sebesar 0,429. Pengaruh tidak langsung $X_{1}$ terhadap $\mathrm{Y}$ melalui $\mathrm{X}_{3}$ sebesar $\rho \mathrm{x}_{3} \mathrm{X}_{1}$. $\rho \mathrm{yx}_{3}=$ $(0,615) \cdot(0,429)=0,264$ dan pengaruh tidak langsung $\mathrm{X}_{2}$ terhadap $\mathrm{Y}$ melalui $\mathrm{X}_{3}$ sebesar $\rho \mathrm{x}_{3} \mathrm{X}_{2}$. $\rho \mathrm{yx}_{3}=(0,372) \cdot(0,429)=0,160$.

Dari kesimpulan penelitian di atas, maka diberikan beberapa saran sebagai berikut: Diharapan kepada pimpinan perguruan tinggi swasta khususnya pada program studi manajemen dan akuntansi dalam rangka meningkatkan kinerja dosen perlu memperhatikan kepemimpinan yang diterapkan melalui budaya organisasi guna mencapai kinerja dosen yang optimal. Diharapkan kepada dosen untuk dapat perguruan tinggi swasta khususnya pada program studi manajemen dan akuntansi menciptakan budaya organisasi atau atmosfir kampus yang kondusif guna mendukung pencapaian kinerja dosen pada khususnya dan perguruan tinggi pada umumnya.

\section{DAFTAR RUJUKAN}

Ambar, 2003, Manajemen Sumber Daya Manusia. Konsep, Teori dan Pengembangan dalam Konteks Organisasi Publik. Graha Ilmu, Yogyakarta.

Bahri, 2010, Optimalisasi Kinerja Kepala Sekolah, Gibon Media Group, Jakarta.

Danim, 2005, Pengembangan Profesi Guru, dari Pra Jabatan, Induksi ke Profesional Madani, Kencana Prenada Media Group, Jakarta.

Daryanto, 2011, Kepala Sekolah sebagai Pemimpin Pembelajaran, Gava Media, Yogyakarta.

Kadarisman, 2012, Manajemen Kompensasi, PT. Rajagrafindo Persada, Jakarta.

Luthans, 2006, Work Volvos and Commitment International, Journal Manpower, Vol 17.3.

Mangkunegara, 2002, Manajemen Sumber Daya Manusia Perusahaan., PT. Remaja Rosdakarya, Bandung. 
Mathis, 2009, Manajemen Sumber Daya Manusia, Salemba Empat, Jakarta

Moekijat, 2001, Manajemen Personalia dan Sumber Daya Manusia. Mandar Maju, Bandung.

Mulyasa, 2006, Manajemen Berbasis Sekolah Konsep, Strategi dan Implementasi, Bandung : PT. Remaja Rosdakarya

Ndraha, 2010, Teori Budaya Organisasi. Rhineka Cipta, Jakarta.

Pabundu Tika, 2010, Budaya Organisasi dan Peningkatan Kinerja Perusahaan, Bumi Aksara, Jakarta.

Pamudji, 2005, Kepemimpinan Pemerintahan Indonesia, Jakarta: Bumi Aksara.

Pangabean, 2004, Manajemen Sumber Daya Manusia. Galia Indonesia, Bogor

Peraturan Menteri Pendidikan Nasional Republik Indonesia No. 19 Tahun 2008 tentang perguruan tinggi penyelenggara sertifikasi dosen

Peraturan No. 20 Tahun 2008 tentang penetapan in passing pangkat dosen bukan pegawai negeri sipil

Purwanto, 2010, Administrasi dan Supervisi Pendidikan, PT. Remaja Rosdakarya, Bandung

Ridwan, 2011, Cara Menggunakan dan Memaknai Path Analysis, Alphabeta, Bandung
Robbins, 2008, Perilaku Organisasi, Terjemahan Tim Indeks. Indeks Garamedia, Jakarta.

Siagian, 2008, Manajemen Sumber Daya Manusia, Bumi Aksara, Jakarta.

Sopiah, 2008, Perilaku Organisasional, Andi, Yogyakarta.

Sutrisno, 2010, Budaya Organisasi, Kencana Prenada Media Group, Jakarta.

Teguh, 2003, Manajemen Sumber Daya Mausia, Konsep, Teori dan Pengembangan dalam Konteks Organisasi Publik, Graha Ilmu, Yogyakarta.

Tika, 2005, Budaya Organisasi dan Peningkatan Kinerja Perusahaan, Bumi Aksara, Jakarta.

Wahyudi, 2009, Meningkatkan Kinerja BUMN: Antisipasi Terhadap Kompetensi dan Deregulasi, Yogyakarta: JKAP No1

Wibowo, 2008, Manajemen Kinerja, Rajawali Press, Jakarta.

Widyastuty, 2007, Pengaruh Insentif terhadap Prestasi Kerja Pegawai, Tesis, UNAIR.

Wirawan, 2008, Budaya dan Iklim Organisasi Teori Aplikasi Penelitian, Salemba Empat, Jakarta. 